Фармацевтичний менеджмент, маркетинг та логістика

Pharmaceutical management, marketing and logistics

УДК $339.138: 615.12: 615.2: 001.895$

DOI https://doi.org/10.11603/2312-0967.2019.1.9963

\title{
МАРКЕТИНГОВИЙ ПІДХІД ДО УДОСКОНАЛЕННЯ УПРАВЛІННЯ ІННОВАЦІЙНИМ ПРОДУКТОВИМ ПОРТФЕЛЕМ ФАРМАЦЕВТИЧНОГО ПІДПРИЄМСТВА
}

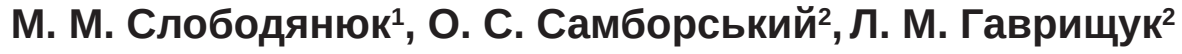 \\ Національний фрармацевтичний університет ${ }^{1}$, Харків \\ ДВНЗ «Івано-Франківський національний медичний університет»² \\ aptekar05@ukr.net
}

\begin{abstract}
Мета роботи. Дослідити вплив складових маркетингового підходу до управління інноваційним продуктовим порторелем фрармацевтичного підприємства на результативність та економічну ефективність розробок генеричних лікарських засобів (ЛЗ).

Матеріали і методи. У якості матеріалів використовували звітні дані про виконані науково-дослідні роботи щодо розробки ЛЗ, звітні дані ВАТ ХФЗ «Червона Зірка» за період 1999-2000 рр. щодо виробництва та збуту ЛЗ, наукові публікації, власні дослідження та результати моніторингу роздрібного ринку ліків компанії «Моріон»; методи: систематизації теоретичного і практичного матеріалу, маркетингового аналізу, порівняльний й економічний методи, метод описового узагальнення. Дана робота має ретроспективний характер.

Результати й обговорення. Проведено опрацювання матеріалів щодо маркетингового підходу до удосконалення управління інноваційним продуктовим портоелем при розробці генеричних ЛЗ фармацевтичним виробничим підприємством (ФВП). Проаналізовано комплексний підхід для реалізації інноваційної продуктової політики підприємства та управління продуктовим портфелем. Висвітлено маркетингові складові та їх застосування у комплексному технологічному процесі створення генеричних Л3, постановки на виробництво та виведення їх на ринок. Визначення економічної едективності проведено на прикладі таблетованих генеричних препаратів диклофенаку, дротаверину (торгова назва Но-Кру-ша), піроксикаму, мазі «Гіоксизон», що одночасно впроваджувались у виробництво. Проаналізовано виробничі та економічні показники 24 серій випуску продукції за 18 місяців. Встановлено, що згідно з ринковим попитом більше 70 \% обсягу нової продукції становили таблетки диклосренаку 0,05 г, рентабельність яких склала 88,04 \%. Визначено низьку рентабельність (14,19 \%) таблеток Но-Кру-ша 0,04 г. Збитковими за досліджуваний період виявились два лз: таблетки Но-Кру-ша 0,04 г й мазь «Гіоксизон» 15 г. 3 початку постановки на виробництво та виходу на ринок за 18 міс., що аналізувались, проведено повернення всіх інвестованих коштів та отримано більше одного млн грн додаткового прибутку. При цьому частка прибутку, що генерували таблетки диклофенаку 0,05 г, склала 96,47 \%.

Висновки. Узагальнено сутність та доцільність комплексного маркетингового підходу до управління продуктовими проектами з розробки Л3. Сорормовано блок-схему моделі щодо удосконалення управління продуктовим проектом із розробки Лз на основі маркетингового підходу. Проаналізовано звітні матеріали виробника та фрірми-розробника щодо одночасної реалізації кількох індивідуальних проектів інноваційного продуктового портоелю із розробки та виведення на ринок генеричних Л3. Обґрунтовано доцільність та економічну ефективність використання маркетингового підходу у формуванні пріоритетності при плануванні поетапної реалізації індивідуальних продуктовихпроектів. Розрахункипоказали, що маркетинговий підхіддає змогупідвищити ефективність продуктових проектів з розробки ЛЗ та значною мірою використовувати принципи самофрінансування та рефрінансування.
\end{abstract}

Ключові слова: лікарські засоби; ефективність розробок; черговість розробок; маркетинговий підхід; інноваційний процес; інноваційний продуктовий портсрель.

Вступ. Забезпечення населення більш якісними, безпечними та доступними ЛЗ підтримується активною інноваційною діяльністю орармацевтичних підприємств. 3 кожним роком пошук та розробка ЛЗ ускладнюється, терміни досліджень суттєво збільшуються від 3-5 (для генеричних та гібридних) до 11-15 років (для оригінальних) ЛЗ та вартість від кількох десятків млн до 1-4 млрд дол. США $[1,2,3]$. Вимоги суспільства та держави щодо зниження відносної вартості та скорочення терміну розробок змушують розробників та виробників удосконалювати складний організаційно-технологічний процес створення Л3, оптимізувати окремі процеси, прогнозувати та мінімізувати ризики на стадіях розробки таких лЗ. Вирішенню таких завдань можуть сприяти попередні маркетингові та економічні дослідження, визначення основних показників, формування індивідуальних продуктових проектів та черговість виконання таких проектів [4, 5, 6]. Аналіз економічної ефективності проекту з розробки ЛЗ дає об'єктивне обґрунтування для прийняття кінцевого рішення менеджментом виробника й бюджетного контролю в процесі його реа-

ISSN 2312-0967. Фармацевтичний часопис. 2019. № 1 
лізації. Набір маркетингових та економічних методів, що використовуються, може бути різним: як повним, так і частковим. У цілому маркетинговий підхід при виборі індивідуальних продуктових проектів, обґрунтуванні їх ефрективності та інвестиційної привабливості стає суттєвою запорукою підвищення результативності та ефективності інноваційної діяльності в цілому. Контроль за використанням фінансових ресурсів, їх економія повинні базуватись на достатньо обґрунтованих прогнозних маркетингових й економічних показниках, що характеризують результативність та ефрективність проекту.

Мета роботи - дослідити вплив складових маркетингового підходу до управління інноваційним продуктовим портфелем фрармацевтичного підприємства на результативність та економічну ефективність розробок генеричних ЛЗ.

Матеріали і методи. У якості матеріалів використовували звіти про виконані науково-дослідні роботи щодо розробки Л3, звітні дані щодо виробництва продукції, наукові публікації, власні дослідження та результати моніторингу роздрібного ринку ліків компанії «Моріон»; методи: систематизації теоретичного (маркетингові рішення та підхід) і практичного (аналіз звітних даних щодо одночасної розробки ряду генеричних ЛЗ виробником, дані конкретних випусків продукції) матеріалу, маркетингового (виокремлення складових маркетингового підходу в управлінні продуктовим порторелем підприємства, опрацювання блоксхеми удосконалення управління продуктовим проектом) аналізу, порівняльний (порівняльні дослідження показників щодо ефективності й перспективності продуктових проектів) й економічний (опрацювання економічних та маркетингових показників, що характеризують обсяги виробництва конкретних ЛЗ, їх собівартість, прибутковість та рівень рентабельності), метод описового узагальнення (формулювання висновків).

Результати й обговорення. Аналіз наукової літератури щодо висвітлення інноваційних підходів в управлінні технологічним процесом пошуку, розробки та постановки на виробництво ЛЗ, контролю за витратами, визначення економічної ефективності індивідуальних продуктових проектів з метою їх почергового статусу та подальшої поетапної реалізації показує, що дослідження лише окремих складових проектів, процесів або етапів робіт з цієї тематики висвітлювались у працях Байгуш Ю. В. [7], Демкіна І. В. [8], Коваленко Св. М. [9], Малого В. В. [10], Хонл Т. А. [11]. У роботі Посилкіної О. В. запропоновано модель управління проектними ризиками, що адаптована до умов фрармацевтичної галузі. Автором рекомендована шкала ступеня ризикованості й розмір премій за ризик для інвестиційних проектів у фрармацевтичному виробництві [12]. У роботі Ушеренко С. В. підкреслюється поточний дефіцит грошових коштів на фрінансування інноваційної діяльності навіть у провідного виробника ліків [13]. В цілому висвітлюється доцільність використання маркетингового підходу при орормуванні та реалізації продуктових проектів 3 розробки ЛЗ. Однак у доступних роботах ми не виявили результатів використання комплексу маркетингового підходу при виборі продуктового проекту 3 розробки Л3, обґрунтовані його економічної ефективності та інвестиційної привабливості, а також в процесі його реалізації. Базуючись на попередньо проведених дослідженнях $[2,14,15,16]$, а також наукових публікаціях інших авторів, ми опрацювали й сорормували блок-схему моделі удосконалення управління продуктовим проектом з розробки ЛЗ на основі маркетингового підходу (рис. 1).

Дані рисунка 1 підтверджують що маркетинговий підхід до вибору розробки ЛЗ повинен включати попередній маркетинговий й економічний аналізи із наступним визначенням вартості проекту, його узагальнених показників ефективності та привабливості проекту, що дають підґрунтя для раціонального прийняття рішення. Одночасно нагальним стає питання більш широкого використання маркетингового підходу у фрормуванні пріоритетності в плануванні поетапної реалізації індивідуальних проектів. Поєднання такого підходу із економічним аналізом забезпечуватиме менеджмент виробника надійним інструментом розподілення індивідуальних проектів на групи черговості згідно з їх перспективністю, рентабельністю, ємкості сегмента, швидкість охоплення ринку, обсягами продажів у перші роки, рівнем конкуренції, силою конкурентів. Почергове виконання робіт, їх фрінансування, постановки на виробництво та виведення ЛЗ на ринок стає основою в управлінні реалізацією інноваційного порторелю. В конкурентних середовищах при постійному дефіциті фрінансових коштів така почерговість може сприяти появі нового додаткового прибутку та використання його в системі рефрінансування подальших розробок $[13,14]$. Такий підхід набуває стратегічного значення для виробника.

Проведено аналіз звітних даних щодо результативності та економічної ефективності як результатів прийнятих управлінських рішень при управлінні одночасною розробкою ряду генеричних ЛЗ ПАТ ХФЗ «Червона зірка» на етапі стратегічного переводу виробника ЛЗ із виробництва продукції у фрормі субстанцій на випуск готових Л3. Встановлено, що такий етап у розвитку виробника ЛЗ характеризувався вкрай обмеженим часовим періодом та великим дефріцитом фрінансових коштів. Перед керівництвом виробника ЛЗ стало питання максимально оптимізувати організаційно-технологічний процес, задіяти найбільш сучасні форми взаємодії із підрядниками робіт, сорормувати економічно ефективний інноваційний продуктовий порторель із сучасних ЛЗ із можливістю рефрінансування. До виконання робіт на основі договору про розподіл готової продукції як оплату за виконані роботи було залучено науково-дослідницьку консалтингову фрірму (ТОВ ФФ «Вінка»). Встановлений

ISSN 2312-0967. Pharmaceutical review. 2019. № 1 
Фармацевтичний менеджмент, маркетинг та логістика

Pharmaceutical management, marketing and logistics

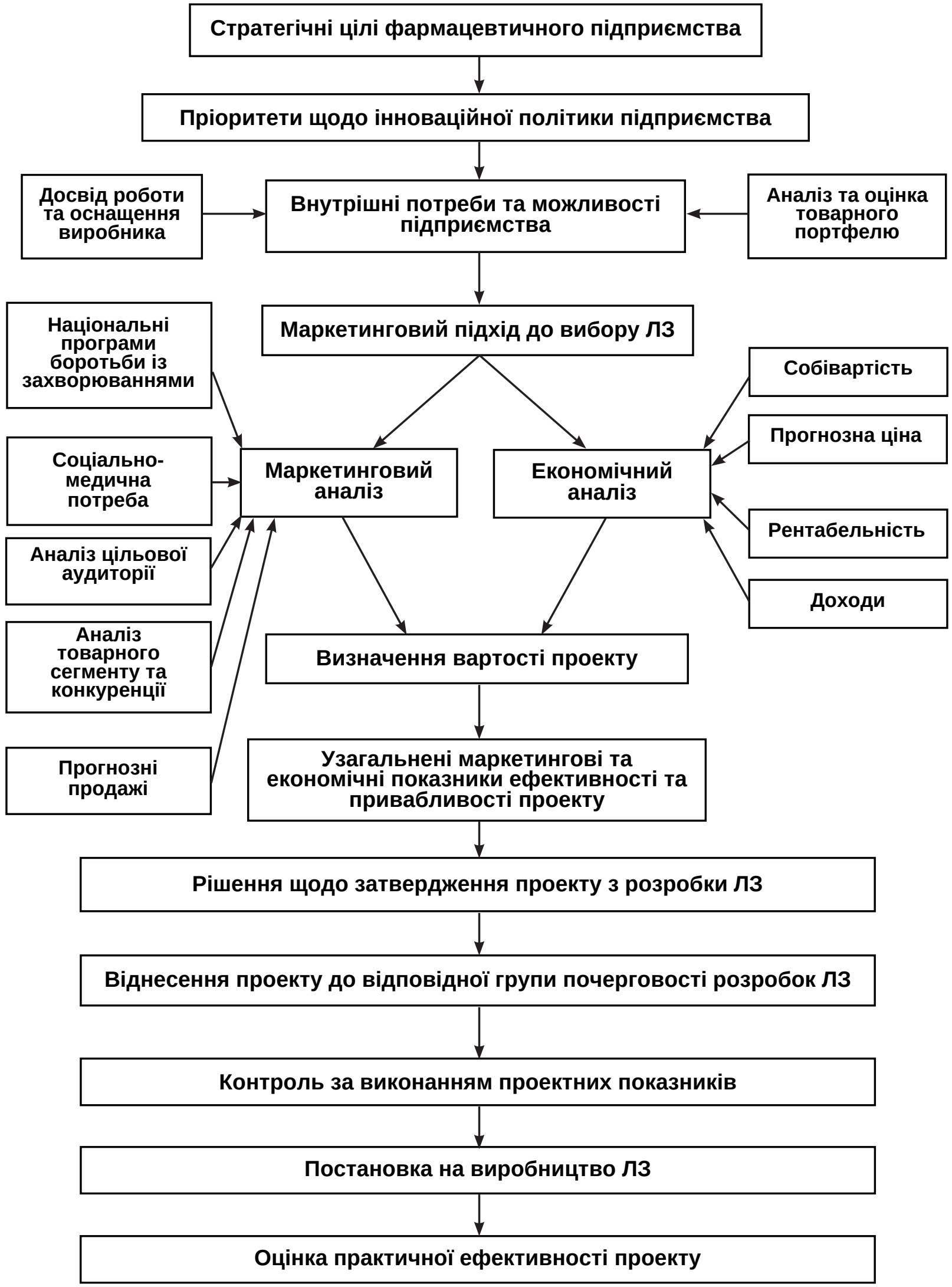

Рис. 1. Блок-схема моделі удосконалення управління продуктовим проектом із розробки лз на основі маркетингового підходу (авторська розробка).

ISSN 2312-0967. Фармацевтичний часопис. 2019. № 1 
механізм взаємодії між учасниками процесу був націлений на кінцевий результат, у якості якого виступав випуск нової продукції. Ми встановили, що консалтинговою фрірмою разом із виробником ЛЗ ще на попередньому етапі було задіяно окремі принципи маркетингового підходу до управління продуктовим портфелем, які включали аналіз товарних сегментів ринку проектних ЛЗ, уточнену фрактичну ємкість конкретних товарних сегментів, виділення активних конкурентів та їх вплив на сегмент, проведенню прогнозування собівартості, прибутковості кожного ЛЗ. Окреслено терміни робіт та виконавців. Таким чином, аналіз, який ми провели, свідчить про часткове задіяння менеджментом підприємства маркетингових рішень і підходів при обґрунтуванні доцільності та привабливості індивідуальних проектів з розробки ЛЗ. На основі отриманих даних фрахівцями було сорормовано кілька блоків продуктового інноваційного портфреля виробника ЛЗ, який складався із індивідуальних проектів різного ступеня щодо їх рентабельності, швидкості охоплення ринку й можливих обсягів продажів у перші роки. Встановлено, що індивідуальні проекти першого блоку були розподілені на чотири умовні групи. При цьому, до першої групи віднесли продукт із високою рентабельністю, широко відомою ринковою назвою, великою ємкістю товарного сегмента ринку, сильною прихильністю лікарів та хворих до ЛЗ, високою його терапевтичною ефективністю та можливими великими обсягами продажів. Друга група характеризувалась продуктом із високою рентабельністю, відомою ринковою назвою, достатньо великою ємкістю ринку, значною прихильністю лікарів та хворих до Лз, значною терапевтичною ефективністю, достатніми обсягами продажів. До третьої групи віднесено продукт із рентабельністю нижче 80 \%, відомою ринковою назвою, обмеженою ємкістю ринку, меншою прихильністю лікарів та хворих. Четверта група включала Лз із низькою рентабельністю (менше $30 \%$ ), власною торговою назвою ще не відомою для ринку й більш сильними ринковими конкурентами. Визначено, що виходячи із можливостей і потреб виробника Л3, до першого блоку увійшло чотири індивідуальні проекти: таблетовані форми генеричних ЛЗ диклофенаку, піроксикаму, дротаверину та мазь «Гіоксизон», які були розподілені наступним чином: таблетки диклофенаку 0,05 г (перша група), таблетки піроксикаму 0,01 г (друга група), мазь Гіоксизон (третя група) і таблетки дротаверину 0,04 г під торговою назвою Но-Кру-ша (четверта група).

У таблиці 1 наведено дані щодо результатів розробки, державної реєстрації названих ЛЗ та постановки їх на виробництво.

Таким чином, можна виокремити результативну організаційну діяльність менеджменту виробника щодо постановки ЛЗ на виробництво.

Економічну ефрективність робіт визначали згідно 3 орієнтованими на ринковий попит обсягами випусків кожного препарату з урахуванням ціни, обсягів промислового випуску в натуральних та грошових одиницях, собівартості продукції та прибутку. У таблиці 2 наведено результати такого аналізу за перші 18 місяців досліджуваного періоду.

Узагальнені результати основних економічних показників наведено в таблиці 3.

Таблиця 1. Узагальнена характеристика проектів лікарських засобів

\begin{tabular}{|l|c|c|}
\hline \multicolumn{1}{|c|}{ Назва лікарського засобу } & $\begin{array}{c}\text { Загальна сума інвестиційних } \\
\text { вкладень, тис. грн }\end{array}$ & $\begin{array}{c}\text { Проміжок часу між датою державної } \\
\text { реєстрації та датою першого промислового } \\
\text { випуску }\end{array}$ \\
\hline Таблетки диклосренаку 0,05 г & 113262,54 & 4 дні \\
\hline Мазь «Гіоксизон» 15 г & 87200,81 & 6 днів \\
\hline Таблетки Но-Кру-ша 0,04 г & 108653,76 & 16 днів \\
\hline Таблетки піроксикаму 0,01 г & 117865,34 & 12 днів \\
\hline Всього & 426982,45 & - \\
\hline
\end{tabular}

Таблиця 2. Промислові випуски лікарських засобів та їх характеристика

\begin{tabular}{|c|c|c|c|c|c|}
\hline $\begin{array}{l}\text { № } \\
3 / \text { ח }\end{array}$ & $\begin{array}{c}\text { Назва ЛЗ, серія, період випуску } \\
\text { згідно з активами }\end{array}$ & $\begin{array}{c}\text { Обсяг } \\
\text { промислового } \\
\text { виробництва, уп. }\end{array}$ & $\begin{array}{c}\text { Обсяг } \\
\text { промислового } \\
\text { виробництва, грн } \\
\end{array}$ & $\begin{array}{c}\text { Собівартість } \\
\text { продукції, } \\
\text { грн } \\
\end{array}$ & $\begin{array}{l}\text { Прибуток, } \\
\text { грн }\end{array}$ \\
\hline 1 & 2 & 3 & 4 & 5 & 6 \\
\hline 1. & $\begin{array}{l}\text { Таблетки диклофренаку 0,05 г № 30; } \\
\text { №1, червень }\end{array}$ & 50710 & 131846,00 & 62586,00 & 69260,00 \\
\hline 2. & $\begin{array}{l}\text { Таблетки диклофренаку 0,05 г № 30; } \\
\text { №2, червень }\end{array}$ & 80000 & 208000,00 & 97760,00 & 110240,00 \\
\hline 3. & Мазь «Гіоксизон» 15 г, №1, червень & 29700 & 100980,00 & 63781,19 & 37198,81 \\
\hline 4. & $\begin{array}{l}\text { Таблетки диклофенаку 0,05 г № 30; } \\
\text { №3, серпень }\end{array}$ & 44850 & 116610,00 & 55344,00 & 61266,00 \\
\hline
\end{tabular}

ISSN 2312-0967. Pharmaceutical review. 2019. № 1 
Фармацевтичний менеджмент, маркетинг та логістика

Pharmaceutical management, marketing and logistics

Продовження табл. 2

\begin{tabular}{|c|c|c|c|c|c|}
\hline 1 & 2 & 3 & 4 & 5 & 6 \\
\hline 5. & $\begin{array}{l}\text { Таблетки диклофенаку 0,05 г № 30; } \\
\text { №4, вересень }\end{array}$ & 30110 & 78286,00 & 28714,56 & 49571,44 \\
\hline 6. & Мазь «Гіоксизон» 15 г, № 2, вересень & 28740 & 97716,00 & 47714,00 & 50002,00 \\
\hline 7. & $\begin{array}{l}\text { Таблетки диклосренаку 0,05 г № 30; } \\
\text { № 5, листопад }\end{array}$ & 47930 & 124618,00 & 58196,61 & 66421,39 \\
\hline 8. & $\begin{array}{l}\text { Таблетки піроксикаму 0,01 г № 20; } \\
\text { листопад }\end{array}$ & 69952 & 181875,20 & 50913,0 & 130962,2 \\
\hline 9. & $\begin{array}{l}\text { Таблетки диклосренаку 0,05 г № 30; } \\
\text { № 6, грудень }\end{array}$ & 51990 & 135174,00 & 69416,55 & 65757,45 \\
\hline 10. & $\begin{array}{l}\text { Таблетки Но-Кру-ша 0,04 г № 20; } \\
\text { № 1, листопад }\end{array}$ & 11785 & 44783,00 & 39880,32 & 7102,68 \\
\hline 11. & $\begin{array}{l}\text { Таблетки Но-Кру-ша 0,04 г № 20; } \\
\text { № 2, листопад }\end{array}$ & 44970 & 128164,50 & 115042,33 & 13122,17 \\
\hline 12. & $\begin{array}{l}\text { Таблетки Но-Кру-ша 0,04 г № 30; } \\
\text { № 3, грудень }\end{array}$ & 21960 & 83448,00 & 71170,98 & 12277,02 \\
\hline 13. & $\begin{array}{l}\text { Таблетки Но-Кру-ша 0,04 г № 30; } \\
\text { № 4, грудень }\end{array}$ & 11785 & 44783,00 & 38117,72 & 6665,28 \\
\hline 14. & $\begin{array}{l}\text { Таблетки диклофенаку 0,05 г № 30; } \\
\text { № 7, січень }\end{array}$ & 55350 & 143910,00 & 84525,40 & 59384,60 \\
\hline 15. & $\begin{array}{l}\text { Таблетки диклофенаку 0,05 г № 30; } \\
\text { № 8, лютий }\end{array}$ & 49985 & 129961,00 & 81805,95 & 48155,05 \\
\hline 16. & $\begin{array}{l}\text { Таблетки диклофенаку 0,05 г № 30; } \\
\text { № 9, березень }\end{array}$ & 48155 & 125203,00 & 59620,48 & 65582,52 \\
\hline 17. & $\begin{array}{l}\text { Таблетки Но-Кру-ша 0,04 г № 30; } \\
\text { № 5, березень }\end{array}$ & 27268 & 103618,40 & 88588,80 & 15029,60 \\
\hline 18. & $\begin{array}{l}\text { Таблетки диклофренаку 0,05 г № 30; } \\
\text { № 10, березень }\end{array}$ & 37797 & 111501,15 & 91338,00 & 20163,15 \\
\hline 19. & $\begin{array}{l}\text { Таблетки диклофенаку 0,05 г № 30; } \\
\text { № 11, квітень }\end{array}$ & 57000 & 168150,00 & 97977,29 & 70172,71 \\
\hline 20. & $\begin{array}{l}\text { Таблетки диклофенаку 0,05 г № 30; } \\
\text { № 12, червень }\end{array}$ & 80000 & 236000,00 & 112380,95 & 123619,05 \\
\hline 21. & $\begin{array}{l}\text { Таблетки піроксикаму 0,01 г № 20; } \\
\text { № 2, серпень }\end{array}$ & 75000 & 195000,00 & 92857,98 & 102142,02 \\
\hline 22. & $\begin{array}{l}\text { Таблетки диклосренаку 0,05 г № 30; } \\
\text { № 13, вересень }\end{array}$ & 44037 & 129909,15 & 63680,96 & 66228,19 \\
\hline 23. & $\begin{array}{l}\text { Таблетки диклофенаку 0,05 г № 10; } \\
\text { № 14, листопад }\end{array}$ & 150000 & 120000,00 & 58536,58 & 61463,42 \\
\hline \multirow[t]{2}{*}{24.} & $\begin{array}{l}\text { Таблетки диклофенаку 0,05 г № 10; } \\
\text { № 15, листопад }\end{array}$ & 304000 & 243200,00 & 115809,52 & 127390,48 \\
\hline & Усього & 1453074 & 3182736,40 & 1745759,17 & 1439177,23 \\
\hline
\end{tabular}

Таблиця 3. Основні економічні показники виробництва лікарських засобів

\begin{tabular}{|c|c|c|c|c|c|}
\hline Лікарський засіб & $\begin{array}{c}\text { К-сть } \\
\text { випусків } \\
\text { серій л3 } \\
\end{array}$ & $\begin{array}{c}\text { Обсяг } \\
\text { промислового } \\
\text { виробництва, грн }\end{array}$ & $\begin{array}{c}\text { Сума одержаного } \\
\text { прибутку, грн; } \\
\text { рентабельність (\%) }\end{array}$ & $\begin{array}{c}\text { Сума } \\
\text { вкладених } \\
\text { інвестицій, грн } \\
\end{array}$ & $\begin{array}{l}\text { Різниця прибутку } \\
\text { та інвестицій, грн }\end{array}$ \\
\hline $\begin{array}{l}\text { Таблетки } \\
\text { диклофренаку 0,05 г }\end{array}$ & 15 & 2305986,70 & $\begin{array}{c}1079705,05 \\
\text { R= 88,04 }\end{array}$ & 113262,54 & $+966442,50$ \\
\hline $\begin{array}{l}\text { Мазь «Гіоксизон» } \\
15 \text { г }\end{array}$ & 2 & 198696,00 & $\begin{array}{l}87200,81 \\
R=78,21\end{array}$ & 97564,32 & $-10363,51$ \\
\hline $\begin{array}{l}\text { Таблетки } \\
\text { піроксикаму 0,01 г }\end{array}$ & 2 & 376875,20 & $\begin{array}{l}233104,22 ; \\
R=162,14\end{array}$ & 117865,34 & $+115238,88$ \\
\hline $\begin{array}{l}\text { Таблетки Но-Кру- } \\
\text { ша } 0,04 \text { г }\end{array}$ & 5 & 301178,50 & $\begin{array}{c}39167,15 \\
R=14,19\end{array}$ & 108653,76 & $-69486,61$ \\
\hline Усього & 24 & 3182736,40 & 1439177,23 & 437345,96 & +1 001831,30 \\
\hline
\end{tabular}

ISSN 2312-0967. Фармацевтичний часопис. 2019. № 1 
Як свідчать дані таблиці 3, за досліджуваний період повністю окупили себе два лз: таблетки диклофенаку 0,05 г 62,5 \% серій, 72,45 \% випуску в натуральних одиницях та 75,02 \% у грошових одиницях та таблетки піроксикаму 0,01 г - 11,84 \%. Л3 Но-Кру-ша 0,04 г- 9,46 \%; мазь «Гіоксизон» 15 г. - 6,24\%. Рентабельність відповідно склала: 88,04; 162,14; 14,19 й $78,21 \%$

Причому таблетки диклофенаку 0,05 г за два випуски (червень місяць), таблетки піроксикаму 0,01 г за один випуск (листопад). Сформований таким чином блок продуктового портфелю дозволив підприємству швидко отримати таку суму прибутку, яка окупила витрати на всі Л3 і отримати додатковий прибуток більше одного млн грн. Остання грошова сума та прибутки із подальших випусків й реалізації цих препаратів були направлені на фрінансування інших проектів ЛЗ із продуктового інноваційного порторелю.

Таким чином, проведений аналіз практично підтвердив високу еорективність використання маркетингового підходу до формування й реалізації продуктових проектів з розробки Лз та черговості їх впровадження у рамках продуктових порторелів.

Висновки. 1. Узагальнено сутність маркетингового підходу до управління інноваційним продуктовим проектом й портфелями та сформовано блок-схему моделі удосконалення управління.

2. На основі аналізу звітних даних виробника лЗ встановлено використання окремих маркетингових рішень при формуванні й реалізації продуктових проектів з розробки ЛЗ, які базувались на маркетинговому та економічному підходах.

3. За результатами оцінки рівня рентабельності, ємкості товарного сегменту, прихильності лікарів та споживачів менеджментом виробника Л3 із консалтинговою фрірмою за перспективністю виділено в продуктовому портфелі блоки й групи індивідуальних проектів з розробки ЛЗ, які розподілено щодо черговості розробок та впровадження на виробництво.

4. Потреба в інвестиційних вкладеннях на розроб- ку чотирьох Л3 склала 426 982,45 грн, у тому числі: таблетки диклофенаку 0,05 г - 113 262,54 грн; таблетки Но-Кру-ша 0,04 г - 108 653,76 грн; таблетки піроксикаму 0,01 г - 117 865,34 грн та мазь «Гіоксизон» - 87 200,81 грн.

5. Згідно із ринковим попитом за період, що аналізувався, випущено таблеток диклосренаку 0,05 г п'ятнадцять серій, таблеток Но-Кру-ша 0,04 г - чотири серії, таблеток піроксикаму 0,01 г - дві серії та мазі «Гіоксизон» 15 г - одна серія із загальним обсягом промислового випуску 1381074 уп. на суму 3182 736,40 грн. Найбільший обсяг виробництва склали таблетки диклофенаку 0,05 г: 62,5 \% серій, 72,45 \% випуску у натуральних одиницях та 75,02 \% у грошових одиницях.

6. Встановлено, що згідно з ринковим попитом частка таблеток диклофренаку 0,05 г у продажах л3 цієї групи склала 72,45 \%; таблеток Но-Кру-ша 0,04 г - 9,46 \%; таблеток піроксикаму 0,01 г - 11,84 \% й мазі «Гіоксизон» 15 г - 6,24 \%. Рентабельність відповідно склала: 88,04; 14,19; 162,14 й 78,21 \%.

7. Повне повернення інвестиційних коштів отримано від таблеток диклофенаку 0,05 г - за два (прибуток 179500 грн) й від таблеток піроксикаму 0,01 г - за один промисловий випуск (прибуток 130962,2 грн). В той же час прибуток від продажів мазі «Гіоксизон» 15 г $(87200,81$ грн) та таблеток Но-Кру-ша 0,04 г (39167,15 грн) за всі 18 місяців періоду, що аналізувався, не дозволили повернути інноваційні вкладення.

8. Опрацьований маркетинговий підхід при виборі ЛЗ як продуктового проекту, включення його в продуктовий інноваційний порторель, визначення почерговості розробки та фрінансування використовується при фрормуванні та реалізації інноваційних продуктових порторелів ФвП (наприклад, ТОВ ФК «Здоров'я», ПАТ «Фармак», ПАТ НВЦ «Борщагівський ХФЗ»).

Конфрлікт інтересів: відсутній.

Conflicts of interest: author has no conflict of interest to declare.

\title{
МАРКЕТИНГОВЫЙ ПОДХОД К СОВЕРШЕНСТВОВАНИЮ УПРАВЛЕНИЯ ИННОВАЦИОННЫМ ПРОДУКТОВЫМ ПОРТФЕЛЕМ ФАРМАЦЕВТИЧЕСКИХ ПРЕДПРИЯТИЙ
}

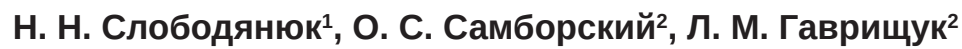 \\ Национальный фрармацевтический университет, ${ }^{1}$ Харьков \\ ГВУЗ «Ивано-Франковский национальный медицинский университет»² \\ aptekar05@ukr.net
}

Цель работы. Исследовать влияние маркетингового подхода к управлению инновационным продуктовым портфелем фрармацевтического предприятия на результативность и экономическую эффективность разработок генерических лекарственных средств (ЛС).

Материалы и методы. В качестве материалов использовали отчеты о выполненных научно-исследовательских работ по разработке ЛС, отчетные данные ОАО ХФЗ «Красная Звезда» за период 1999-2000 гг. по производству и отгрузке ЛС, научные публикации, собственные исследования и результаты мониторинга розничного рынка

ISSN 2312-0967. Pharmaceutical review. 2019. № 1 
Фармацевтичний менеджмент, маркетинг та логістика

Pharmaceutical management, marketing and logistics

лекарств компании «Морион»; методы: систематизации теоретического и практического материала, маркетингового анализа, сравнительный и экономический методы, метод описательного обобщения.

Эта работа носит ретроспективный характер.

Результаты и обсуждение. Проведено обработку материалов по маркетинговому подходу к совершенствованию управления инновационным продуктовым портоелем при разработке генерических ЛС фрармацевтическим производственным предприятием (ФПП). Проанализировано комплексный подход к реализации инновационной продуктовой политики предприятия и управления продуктовым портфелем. Освещены маркетинговые составляющие и их применение в комплексном технологическом процессе создания генерических ЛС, постановки на производство и вывод их на рынок. Определение экономической эффеективности проведено на примере таблетированных генерических препаратов диклофенака, дротаверина, пироксикама, мази «Гиоксизон», которые одновременно внедрялись в производство. Проанализированы производственные и экономические показатели 24 серий выпуска продукции за 18 месяцев. Установлено, что согласно рыночному спросу более 70 \% объема новой продукции составляли таблетки диклосренака 0,05 г, рентабельность которых составила 88,04 \%. Определено низкую рентабельность (14,19 \%) таблеток Но-Кру-ша 0,04 г. Не окупились за исследуемый период два лС: таблетки Но-Кру-ша 0,04 г и мазь «Гиоксизон» 15 г. С начала постановки на производство и выхода на рынок за 18 мес., что анализировались, проведено возвращение всех инвестированных средств и получено более одного млн грн дополнительной прибыли. При этом доля прибыли таблеток диклофенака 0,05 г составила 96,47 \%.

Выводы. Обобщено сущность и целесообразность комплексного маркетингового подхода к управлению продуктовыми проектами по разработке ЛС. Сформирована блок-схема модели для совершенствования управления продуктовым проектом по разработке лс на основе маркетингового подхода. Проанализированы отчетные материалы производителя и фрирмы-разработчика по одновременной реализации нескольких индивидуальных проектов инновационного продуктового портореля по разработке и выводе на рынок генерических ЛС. Обоснована целесообразность и экономическая эффективность использования маркетингового подхода в фрормировании приоритетности при планировании поэтапной реализации индивидуальных продуктовых проектов. Расчеты показали, что маркетинговый подход позволяет повысить эффеективность продуктовых проектов по разработке лС и в значительной степени использовать принципы самофинансирования и рефинансирования.

Ключевые слова: лекарственные средства; эффективность разработок; очередность разработок; маркетинговый поход; инновационный процесс; инновационный продуктовый портфель.

\title{
MARKETING APPROACH TO THE IMPROVING OF A PHARMACEUTICAL ENTERPRISE INNOVATIVE PRODUCT PORTFOLIO MANAGEMENT
}

\author{
M. M. Slobodyanyuk' ${ }^{1}$ O. S. Samborskyi², L. M. Havryshchuk ${ }^{2}$ \\ National University of Pharmacy, Kharkiv ${ }^{1}$ \\ Ivano-Frankivsk National Medical University ${ }^{2}$ \\ aptekar05@ukr.net
}

The aim of the work. Research the influence of marketing approach components to the pharmaceutical enterprise innovative product portfolio management on the results and economic efficiency of generic medicines developments.

Materials and Methods. As materials, we used reports of scientific-research works carried out on the medicines development, reporting data of OJSC CPF "Red Star" for the 1999-2000 period about medicines production and marketing, scientific publications, individual investigations and results of medicines produced by "Morion" company retail market monitoring; as methods: theoretical and practical materials systematization, marketing analysis, comparative and economic methods, descriptive generalization method. This work is retrospective.

Results and Discussion. The materials on the marketing approach to the innovative product portfolio management improvement in the generic medicines development by pharmaceutical manufacturing enterprise (PME) were studied. It was analyzed a complex approach for the enterprise innovative product policy implementation and the product portfolio management. We singled out marketing components and their use in complex technological process of generic medicines development, putting into production and taking to the market. The economic efficiency research was conducted on the example of the pilled generic medicines of Diclofenak, Drotaverin, Piroxycam, Gioxyson ointment, which were simultaneously introduced into production. It was analyzed production and economic indicators of 24 product series manufacturing for 18 months. It was determined that according to the market demand more than $70 \%$ of new products were the pills Diclofenak $0.05 \mathrm{~g}$, the profitability of which amounted to $88.04 \%$. It was found out a low profitability (14.19 \%) of the pills No-Kru-sha $0.04 \mathrm{~g}$. Two medicines turned out to be not self-sustainable during the investigation period: pills No-Kru-sha $0.04 \mathrm{~g}$ and Gioxyson ointment $15 \mathrm{~g}$. From the time of putting into production and taking to the market for $18 \mathrm{months}$, which were analyzed, it was returned all the costs invested and received more than a million hryvnia of additional income. Thus, the income earned by the pills Diclofenak $0.05 \mathrm{~g}$ amounted to $96.47 \%$.

ISSN 2312-0967. Фармацевтичний часопис. 2019. № 1 
Conclusions. The essence and expediency of a comprehensive marketing approach to managing product projects for the drugs development were generalized. The block diagram of the model for improving the product project management for the drugs development based on a marketing approach was developed. The report materials of the manufacturer and the firm-developer concerning the simultaneous implementation of several innovative product portfolio individual projects for the development and launching of generic drugs on the market were analyzed. The expediency and economic efficiency of using the marketing approach in the priority formation in the planning of the phased individual product projects implementation were substantiated. The calculations showned that the marketing approach allows to increase the product projects efficiency and to make a significant use of the self-financing and refinancing principles.

Key words: medicines; development efficiency; development order; marketing approach; innovative process; innovative product portfolio.

\section{Список літератури}

1. Drug repositioning: bringing new life to shelved assets and existing drugs / edited by Michael J. Barratt, Donald E. Frail. Printed in the United States of America. - 2012. $-470 \mathrm{c}$.

2. Слободянюк М. М. Теоретичні основи та методика обґрунтування есективності й інвестиційної привабливості розробок та впровадження лікарських засобів на основі проектного планування та комп'ютерної обробки : метод. реком. Український центр наукової медичної інфрормації і патентно-ліцензійної роботи МОЗ України / М. М. Слободянюк, О. С. Самборський. - Київ, 2017. - 36 c.

3. Гребеник К. Лікувальні інвестиції: у що вкладати гроші в українській срармі : Режим доступу : https://mind. ua/publications/20184249-likuvalni-investiciyi-u-shchovkladati-groshi-v-ukrayinskij-farmi

4. Слободянюк М. М. Удосконалення управління технологічним процесом розробки нових лікарських засобів як соціально орієнтованим проектом / М. М. Слободянюк, О. С. Самборський / Соціальна фрармація: стан, проблеми та перспективи : матер. IV міжн. наук.практ. інтернет-конореренції, 24-25 квітня 2018 р. / ред. кол. : А. А. Котвіцька та ін. - Х. : Вид-во НФаУ, 2018. C. 168-171.

5. Самборський О. С. Використання проектного планування в системі прогнозування ефективності та привабливості розробки лікарських засобів в Україні / О. С. Самборський, М. М. Слободянюк // International research and practice conference «Relevant issues of modern medicine: the experience of Poland and Ukraine» : Conference proceedings, October 20-21, 2017. Lublin: Izdevnieciba «Baltija Publishing», 2017. - C. 127-129.

6. Слободянюк М. М. Науково-методичні підходи до оптимізації фрінансування інноваційного портоелю фрармацевтичного підприємства / М. М. Слободянюк, С. В. Жадько, О. С. Самборський // Український журнал клінічної та лабораторної медицини. - 2010. - № 2. C. 58-62.

7. Байгуш Ю. В. Обґрунтування економічної ефрективності та комерційної доцільності впровадження нового антигіпертензивного препарату / Ю. В. Байгуш, М. М. Слободянюк, О. С. Самборський // Управління якістю в фрармації: збірник наук. робіт $X$ наук.-практ. конфрер. 3 міжнародною участю (м. Харків, 20 травня
2016 р.) / ред. кол. : В. О. Лебединець, Ю. В. Підпружников, Ю. І. Губін та ін. - Харків : НФаУ, 2016. C. $18-20$.

8. Демкин И. В. Оценка риска инвестиционных проектов фрармацевтического предприятия / И. В. Демкин, А. В. Стрельцов, И. Д. Галетов // Управление риском. 2004. - № 4. - С. 16-27.

9. Коваленко Св. М. Обґрунтування соціально-медичної доцільності розробки та економічної ефективності таблеток «Тіотарін» / Св. М. Коваленко // Вісник фармації, 2015. - № 4 (84). - С. 47-51.

10. Малий В. В. Маркетинговий підхід до визначення основних показників економічної ефективності гепатотропного лікарського засобу / В. В. Малий, Муса Істаніс Марвек Медхат // Соціальна фрармація в охороні здоров'я. - 2018. - Т 4, № 3. - С. 59-68. doi: 10.24959/ sphhcj.17.82.

11. Хонл Т. А. Затраты на разработку инновационного лекарственного препарата / Т. А. Хонл // Проблемы учета и финнансов. - 2013. - № 2 (10). - С. 52-54.

12. Посилкіна О. В. Управління проектними ризиками у фрармацевтичному виробництві / О. В. Посилкіна // Вісник фрармації. - 2004. - № 3 (39). - С. 59-62.

13. Ушеренко С. В. Вибір джерел фрінансування інвестиційної діяльності підприємства (на прикладі ПАТ «Фармак») / С. В. Ушеренко, Д. Д. Черненко // Часопис економічних ресрорм. - 2015. - № 2 (18). - С. 92-98.

14. Слободянюк М. М. Оцінка привабливості сегменту ринку лікарських препаратів при формуванні товарного асортименту фрармацевтичного підприємства : метод. рек. I М. М. Слободянюк, С. В. Жадько. - Харків, 2008. $-28 \mathrm{c}$.

15. Слободянюк М. М. Теоретичні основи і методичне обґрунтування комплексного аналізу та моделювання доцільності й ефективності розробок нових лікарських засобів / М. М. Слободянюк, О. С. Самборський, Т. Германовскі // Соціальна фрармація в охороні здоров'я. -2017. - Т 3, № 4. - C. 19-31. doi: 10.24959/sphhcj.17.95. 16. Слободянюк М. М. Науково-методичний підхід до прогнозування економічних показників при розробці нових лікарських засобів / М. М. Слободянюк, О. С. Самборський, Т. Германовскі // Управління, економіка та забезпечення якості в фрармації. - 2017. - № 4 (52). C. 50-58. doi: 10.24959/uekj.17.32.

ISSN 2312-0967. Pharmaceutical review. 2019. № 1 
Фармацевтичний менеджмент, маркетинг та логістика Pharmaceutical management, marketing and logistics

\section{References}

1. Michael J Barratt, Donald E Frail. Drug repositioning: bringing new life to shelved assets and existing drugs. Printed in the United States of America; 2012: 470.

2. Slobodianiuk, MM, Samborskyi OS. Theoretical bases and methods of efficiency substantiation and investment attractiveness of development and introduction of medicines on the basis of project planning and computer processing. Guidelines. [Теоретичні основи та методика обґрунтування ефективності й інвестиційної привабливості розробок та впровадження лікарських засобів на основі проектного планування та комп'ютерної обробки: метод. реком.] Ukrainian Center of Scientific Medical Information and Patent and Licensing of the Ministry of Health of Ukraine. Kyiv; 2017. Ukrainian. 3. Hrebenyk K. Medical investment: what to invest in Ukrainian pharmacy: [Electronic resource] - Available from: https://mind.ua/publications/20184249-likuvalni-investiciyiu-shcho-vkladati-groshi-v-ukrayinskij-farmi. Ukrainian.

4. Slobodianiuk MM, Samborskyi OS. Improving the management of the developing new medical facilities technological process as a socially oriented project. Social Pharmacy: Status, Problems and Prospects: Materials of the IV International Scientific and Practical Internet Conference, 2018; April, 24-5; Kharkiv: 168-71. Ukrainian.

5. Samborskyi OS, Slobodianiuk MM. Use of project planning in the system for forecasting the efficiency and attractiveness of drug development in Ukraine. International research and practice conference "Relevant issues of modern medicine: the experience of Poland and Ukraine": Conference proceedings, 2017; October, 20-1. Lublin: Izdevnieciba "Baltija Publishing": 127-9. Ukrainian.

6. Slobodianiuk MM, Zhadko SV, Samborskyi OS. Scientific and methodical approaches to optimization of pharmaceutical enterprise innovative portfolio financing. Ukr zhurn kiln i lab medytsyny. 2010;2: 58-62. Ukrainian.

7. Baihush YuV, Slobodianiuk MM, Samborskyi OS. Justification of economic efficiency and commercial expediency of new antihypertensive drug introduction. Quality ma- nagement in pharmacy: a collection of scientific works of a scientific and practical conference with international participation, 2016; 20 May; Kharkiv: 18-20. Ukrainian.

8. Demkin IV, Streltsov AV, Haletov ID. Risk assessment of a pharmaceutical company investment projects. Upravleniye riskom. 2004;4: 16-27. Russian.

9. Kovalenko SvM. Substantiation of social and medical expediency of Tiotarin pills development and economic efficiency. Visnyk Farmatsii. 2015;4(84): 47-51. Ukrainian.

10. Malyi VV, Musa Istanis Marvek Medkhat. Marketing approach to determining the main indicators of hepatotropic drug economic efficiency. Sotsialna farmatsiia $v$ okhoroni zdorovia. 2018;4(3): 59-68. doi: 10.24959/sphhcj.17.82. Ukrainian.

11. Khonl TA. The cost of developing an innovative drug. Problemy uchota i finansov. 2013;2(10): 52-4. Russian.

12. Posylkina OV. Project risk management in pharmaceutical production. Visnyk Farmatsii. 2004;3(39): 59-62. Ukrainian.

13. Usherenko SV, Chernenko DD. Selection of the enterprise investment activity financing sources (at the example of PJSC "Farmak"). Chasopys ekon. reform. 2015;2(18): 92-8. Ukrainian.

14. Slobodianiuk MM, Zhadko SV. Drug market segment attractiveness assessment in the formation of the pharmaceutical company product range. Guidelines. [Оцінка привабливості сегменту ринку лікарських препаратів при формуванні товарного асортименту фрармацевтичного підприємства : метод. рек.] Kharkiv; 2008. Ukrainian.

15. Slobodianiuk MM, Samborskyi OS, Hermanovski T. Theoretical bases and methodological substantiation of new drugs development expediency and efficiency complex analysis and modeling. Sotsialna farmatsiia v okhoroni zdorovia. 2017;3(4): 19-31. doi: 10.24959/sphhcj.17.95. Ukrainian.

16. Slobodianiuk MM, Samborskyi OS, Hermanovski T. Scientific and methodical approach to prediction of economic indicators in the development of new drugs. Upravlinnia, ekonom ta zabezpech yakosti $v$ farmatsii. 2017;4(52): 50-8. doi: 10.24959/uekj.17.32. Ukrainian.

Надійшла до редакції / Received: 08.02.2019 Після доопрацювання / Revised: 18.02.2019, 09.03.2019 Прийнято до друку / Accepted: 22.03.2019

\section{Відомості про авторів:}

Слободянюк М.М. - Д-р фрармац. н., проф., профр. кафр. фрармацевтичного маркетингу та менеджменту, Національний фрармацевтичний університет, Харків, Україна. E-mile: veritas_kh@ukr.net, ORCID 0000-0001-9328-0539

Самборський О.С. - канд. фрармац. н., доц., доц. кафр. організації та економіки фрармації і технології ліків, Івано-Франківський національний медичний університет, Івано-Франківськ, Україна. E-mail: aptekar05@ukr.net, ORCID 0000-0002-8913-0965

Гаврищук Л.М. - асистент, асистент кафедри організації та економіки фрармації і технології ліків, Івано-Франківський національний медичний університет, Івано-Франківськ, Україна. E-mail: Ihavryshchuk@ifnmu.edu.ua, ORCID 0000-0002-2261-5474

\section{Information about authors:}

Slobodyanyuk M.M. - DS (Pharmaceutical Sciences), Professor, Professor of the Pharmaceutical Marketing and Management Department, National University of Pharmacy, Kharkiv, Ukraine. E-mile: veritas_kh@ukr.net, ORCID 0000-0001-9328-0539

Samborskyi O.S. - PhD (Pharmaceutical Sciences), Associate Professor of the Organization and Economics of Pharmacy and Drug Technology Department, Ivano-Frankivsk National Medical University, Ivano-Frankivsk, Ukraine. E-mail: aptekar05@ukr. net, ORCID 0000-0002-8913-0965

Havryshchuk L.M. - assistant, assistant of the Organization and Economy of Pharmacy and Drug Technology Department, Ivano-Frankivsk National Medical University, Ivano-Frankivsk National Medical University, Ivano-Frankivsk, Ukraine. E-mail: Ihavryshchuk@ifnmu.edu.ua, ORCID 0000-0002-2261-5474

ISSN 2312-0967. Фармацевтичний часопис. 2019. № 1 